Article

\title{
Quantifying Regulating Ecosystem Services with Increased Tree Densities on European Farmland
}

\author{
Josep Crous-Duran ${ }^{1,2, * \mathbb{0}}$, Anil R. Graves ${ }^{3}$, Silvestre García de Jalón ${ }^{4}$, Sonja Kay ${ }^{5}$, \\ Margarida Tomé ${ }^{1} \mathbb{D}$, Paul J. Burgess ${ }^{3}\left(\mathbb{D}\right.$, Michail Giannitsopoulos ${ }^{3}$ and João H.N. Palma ${ }^{1,6}$ \\ 1 Forest Research Centre, School of Agriculture, University of Lisbon, Tapada da Ajuda s/n, 1349-017 Lisbon, \\ Portugal; magatome@isa.ulisboa.pt (M.T.); joaopalma@gmail.com (J.H.N.P.) \\ 2 REVOLVE, Carrer d'Àlaba, 100, 08018 Barcelona, Spain \\ 3 School of Water, Energy and Environment, Cranfield University, Cranfield, Bedfordshire MK43 0AL, UK; \\ a.graves@cranfield.ac.uk (A.R.G.); p.burgess@cranfield.ac.uk (P.J.B.); \\ m.giannitsopoulos@cranfield.ac.uk (M.G.) \\ 4 Basque Center for Climate Change, 48940 Leioa, Spain; silvestre.garciadejalon@bc3research.org \\ 5 Agroscope, CH-8046 Zurich, Switzerland; sonja.kay@agroscope.admin.ch \\ 6 MV Agroecology Research Centre, Moinhos de Vento, Mértola, 7750-217 Espírito Santo, Portugal \\ * Correspondence: jcrous@isa.ulisboa.pt
}

Received: 25 June 2020; Accepted: 9 August 2020; Published: 18 August 2020

check for updates

\begin{abstract}
Agroforestry systems have been compared to agricultural and forestry alternatives, providing a land-use solution for additional environmental benefits while maintaining similar levels of productivity. However, there is scarce research assessing such patterns across a pan-European scale using a common methodology. This study aims to improve our understanding of the role of trees in three different regulating ecosystem services-(1) soil erosion, (2) nitrate leaching and (3) carbon sequestration-in traditional and innovative agroforestry systems in Europe through a consistent modeling approach. The systems' assessment spans environmentally from the Mediterranean environmental region in Portugal to the Continental environmental region in Switzerland and Germany to the Atlantic environmental region in the United Kingdom. Modeled tree densities were compared in the different land-use alternatives, ranging from zero (agriculture with only crops or pasture) to forestry (only trees). The methodology included the use of a biophysical model (Yield-SAFE) where the quantification of the environmental benefits was integrated. Results show a consistent improvement of regulating ecosystem services can be expected when introducing trees in the farming landscapes in different environmental regions in Europe. For all the systems, the forestry alternatives presented the best results in terms of a decrease in soil erosion of $51 \%( \pm 29)$, a decrease of nearly all the nitrate leaching $(98 \% \pm 1)$ and an increase in the carbon sequestration of up to $238 \mathrm{Mg} \mathrm{C}$ $\mathrm{ha}^{-1}( \pm 140)$. However, these alternatives are limited in the variety of food, energy and/or materials provided. On the other hand, from an arable or pure-pasture alternative starting point, an increase in agroforestry tree density could also be associated with a decrease in soil erosion of up to $25 \%( \pm 17)$, a decrease in nitrates leached of up to $52 \%( \pm 34)$ and an increase in the carbon sequestered of $163 \mathrm{Mg}$ $\mathrm{C} \mathrm{ha}^{-1}( \pm 128)$ while at the same time ensuring the same levels of biomass growth and an increase in product diversification.
\end{abstract}

Keywords: Yield-SAFE; process-based model; agroforestry; carbon sequestration; soil erosion; nitrate leaching; montado; short rotation coppice; silvoarable; fruit orchards; tree density

\section{Introduction}

Agroforestry systems (AFS) are attracting the interest of land managers, who are seeking a more efficient way of producing food, bioenergy and materials than found with monoculture agriculture or 
forestry [1]. This is because AFS can enable higher and more diverse biomass production due to the greater capture of solar radiation and water by trees and crops when both are grown together [2].

At the same time, compared to agriculture, agroforestry can reduce soil erosion [3], nitrate leaching [4] and net greenhouse gas emissions [5] while improving biodiversity [6] and enhancing climate change mitigation by sequestering carbon [7]. These sorts of ecosystem benefits that mediate or moderate the effect of the environment on human well-being and health are defined by the Common International Classification of Ecosystem Services (CICES, v5.1) as regulation and maintenance services.

Some studies have focused on the effect of a single agroforestry system on one ecosystem service for one location. However, there have been few studies including different ecosystems services across different sites, which could help establish relationships at broader scales [8]. Because of the difficulty in establishing a full range of practices in a single location, many comparisons of agroforestry with agricultural systems rely on the use of models [9].

In a previous paper, a biophysical model called Yield Estimator for Long term Design of Silvo-arable Agro-Forestry in Europe (Yield-SAFE, [10]), which can predict tree and arable crop growth and yields in agroforestry systems, was used to examine how different densities of trees affected the provisioning services of four contrasting locations and agroforestry systems across Europe [11]. The paper concluded that including trees in pasture or arable systems increased the capture of solar energy and thereby the production of total biomass per unit area in comparison with monoculture forestry, pasture and arable systems, but that the accumulated energy per tree was reduced as tree density increased [11]. The aim of this paper is to act as a companion paper to [10], in order to determine how an increase in tree density and the associated tree-crop interactions for water and radiation interact with the supply across the same sites of three different regulating ecosystem services (RES): regulation of soil erosion, regulation of nitrate leaching and carbon sequestration, with a consistent methodology across Mediterranean, Continental and Atlantic environmental regions in Europe.

\section{Materials \& Methods}

\subsection{Agroforestry Case Study Systems}

Four agroforestry systems were considered for this study: (1) Iberian wood pastures called dehesas in Spain and montados in Portugal with holm oak (MONTPT), (2) grazed cherry orchards in Switzerland (CTCH), (3) poplar silvoarable systems in the United Kingdom (SAFUK) and (4) fast-growing poplar short rotation coppice plantations for energy purposes within arable fields in Germany (SRCDE) (Table 1). These systems (1) represent traditional and innovative agroforestry systems in different climatic conditions and (2) focus on different products (trees, livestock and/or crop components), and (3) there are long-term experimental trials with data available for validation. Each agroforestry system was considered in terms of four agroforestry alternatives (different densities depending on each system), an agriculture (no trees) and a high-density tree-only system. The agriculture systems had no trees. The tree density within each agroforestry alternative was assumed to stay constant throughout the simulation period while the forestry alternatives assumed standard management practice, which typically included a process of thinning to reduce the tree density over time. The simulation period considered was 80 years. A full description has previously been provided [11], but a brief description of each case study is presented here for clarity. 
Table 1. Location, meteorological and soil information and component description of the four agroforestry systems studied.

\begin{tabular}{|c|c|c|c|c|}
\hline & Montado & Cherry Orchards & Silvoarable Systems & Short Rotation Coppice \\
\hline Location & Montemor-o-Novo, Portugal & Gempen, Switzerland & Silsoe, United Kingdom & Forst, Germany \\
\hline Identification & MONTPT & $\mathrm{CTCH}$ & SAFUK & SRCDE \\
\hline Altitude (m asl) & 130 & 680 & 70 & 75 \\
\hline Longitude $\left({ }^{\circ}\right)$ & 38.7023 & 7.2299 & 50.0089 & 51.7890 \\
\hline Latitude $\left({ }^{\circ}\right)$ & -8.3261 & 6.9943 & 0.4358 & 14.4918 \\
\hline \multicolumn{5}{|c|}{ Meteorological conditions } \\
\hline $\begin{array}{l}\text { Mean annual solar radiation } \\
\left(\mathrm{MJ} \mathrm{m}^{-2}\right)\end{array}$ & 6080 & 4340 & 3710 & 4078 \\
\hline $\begin{array}{c}\text { Mean annual temperature } \\
\left({ }^{\circ} \mathrm{C}\right)\end{array}$ & 14.1 & 5.5 & 11 & 7.29 \\
\hline Mean annual rainfall (mm) & 693 & 1157 & 747 & 609 \\
\hline Mean wind speed $\left(\mathrm{m} \mathrm{s}^{-1}\right)$ & 3.65 & 2.2 & 5.43 & 3.61 \\
\hline \multicolumn{5}{|c|}{ Soil data } \\
\hline $\begin{array}{l}\text { Soil texture } \\
\text { Soil depth }(\mathrm{cm})\end{array}$ & $\begin{array}{l}\text { Medium-fine } \\
100\end{array}$ & $\begin{array}{c}\text { Fine } \\
50\end{array}$ & $\begin{array}{l}\text { Very fine } \\
150\end{array}$ & $\begin{array}{l}\text { Medium } \\
100\end{array}$ \\
\hline \multicolumn{5}{|c|}{ Agroforestry components } \\
\hline Tree & Quercusrotundifolia L. & Prunus avium $\mathrm{L}$. & Populus spp. & Populus spp. Max 1 var. \\
\hline Crop & $\begin{array}{l}\text { Non-improved Natural } \\
\text { grasslands (ng) }\end{array}$ & $\begin{array}{l}\text { Non-improved Natural } \\
\text { grasslands (ng) }\end{array}$ & $\begin{array}{l}\text { Wheat (w) } \\
\text { Barley (b) } \\
\text { Oilseed (o) }\end{array}$ & $\begin{array}{l}\text { Sugar beet }(\mathrm{sb}) \\
\text { Wheat }(\mathrm{w})\end{array}$ \\
\hline Crop rotation & none & none & $\mathrm{w} / \mathrm{w} / \mathrm{b} / \mathrm{o}$ & $\mathrm{sb} / \mathrm{w} / \mathrm{sb} / \mathrm{w}$ \\
\hline Livestock & Iberian pig/cattle & Cattle & - & - \\
\hline
\end{tabular}

\subsubsection{Iberian Wood Pastures in Portugal and Spain}

Iberian dehesas and montados occupy an area of around 3.04 million hectares [12] and are characterized by low tree densities (20-50 trees ha ${ }^{-1}$ ) combined with agriculture and/or pastoral activities [13]. Two main tree species are dominant: holm oak (Quercus rotundifolia L.) and cork oak (Quercus suber L.). The dominant tree defines the main economic activity: for cork montado, the main source of revenue is cork extraction, and for holm montado, the main activity is grazing livestock (cattle and/or Iberian pigs). In both cases, cultivation, other than to reseed grassland, is nowadays rare, and the main understory use remains livestock grazing [14]. The six management alternatives analyzed in the montado case study included a pure-pasture option (no trees, MONTPT-A), four agroforestry options with 50 (MONTPT-AF1), 100 (MONTPT-AF2), 150 (MONTPT-AF3) and 200 (MONTPT-AF4) trees ha $\mathrm{h}^{-1}$ and a higher density pure plantation (forestry alternative, MONTPT-F), with 505 trees planted followed by a thinning regime of $435,320,250,200$ and 160 residual tree density in years 9, 45, 55,65 and 75, respectively. It is considered that a regular light pruning occurs every 12 years, removing $10 \%$ of total biomass [15].

\subsubsection{Grazed Cherry Orchards in Switzerland}

Fruit orchards are of great importance in Switzerland [16] and in Central Europe, covering around 0.4 million ha of agricultural land [17]. These systems, typically with a tree density between 20 and 100 trees per hectare, can incorporate an understory crop of grass and/or crops [18]. The main tree species include apple trees (Malus spp.), pear trees (Pyrus spp.) and/or cherry trees (Prunus avium L.) that were planted for fruit and timber production. Management options considered: pure pasture (no trees, CTCH-A); four agroforestry alternatives with 26 (CTCH-AF1), 52 (CTCH-AF2), 78 (CTCH-AF3) and 104 (CTCH-AF4) trees ha ${ }^{-1}$ and a forestry/orchard alternative (CTCH-F) with an initial tree density of 690 trees $^{-1}$ followed by a thinning regime of 395, 270, 190, 142 and 100 residual tree density in years $10,15,25,35$ and 50 , respectively. 


\subsubsection{Silvoarable Systems in the UK}

The silvoarable systems analyzed for the UK (SAFUK) are based on an experimental arrangement planted in 1992 as part of the UK silvoarable network. Four poplar hybrids were planted in lines with an intercropping area allocated to a crop rotation comprising wheat (Triticum spp.), barley (Hordeum vulgare L.), oats (Avena sativa L.) or oilseed rape (Brassica napus L.). This system is not a traditional agroforestry system and, consequently, it is rarely seen in the UK [19]. For this system, the simulation period included four rotations of 20 years each, with trees being replanted at the end of every rotation. In the arable option (no-tree alternative, SAFUK-A), the area is occupied 100\% by the crop while, in the forestry option, the trees were also arranged in lines using the same spacing as in the agroforestry alternatives $(10 \times 6.4 \mathrm{~m})$, with fallow alleys between the lines. The agroforestry tree densities analyzed were 56 (SAFUK-AF1), 78 (SAFUK-AF2), 104 (SAFUK-AF3) and 156 (SAFUK-AF4) trees ha ${ }^{-1}$ where tree density was reduced by increasing the distance within the lines, maintaining a consistent crop area of $80 \%$ of the total area. The forestry alternative (SAFUK-F) started with an initial tree density of 1250 trees ha $^{-1}$ followed by a thinning regime of $938,703,352$ and 158 residual tree density in years 6 , 8,10 and 12 , respectively.

\subsubsection{Short Rotation Coppice Systems in Germany}

The growing of rows of short rotation coppice systems (SRC) within an arable field is an innovative system still not widely represented in Europe. The system consists of planting fast-growing trees in lines for obtaining biomass for energy between cultivated areas. However, these systems seem an interesting option for obtaining energy in rural areas, occupying an area of around 6600 ha in Germany [20]. The main tree species used in these systems include poplar variety Max 1 (Populus nigra $\times$ Poplar maximowiczii), "Fritzi Pauley" clone (Poplar trichocarpa) and black locust (Robinia pseudoacacia). Trees are planted in high densities (around 9000 trees ha-1) in 11-metre-wide rows with crop alleys ranging in widths from 96 to $24 \mathrm{~m}$ (96 m (SRCDE-AF1), $72 \mathrm{~m}$ (SRCDE-AF2), $48 \mathrm{~m}$ (SRCDE-AF3) and $24 \mathrm{~m}$ (SRCDE-AF4) in addition to the no-tree/arable (SRCDE-A) and a forestry/pure SRC (SRCDE-F) alternative.

In the crop alleys, several crops are grown. For this study, winter wheat (Triticum aestivum L.) and sugar beet (Beta vulgaris L.), grown alternatively, were considered. The tree coppicing rotation was assumed to be four years, enabling 20 rotations for the 80 years of the period simulated. In the simulation, in order to prevent the legal redesignation [21] of the poplar areas as "forest", the trees were replanted every third rotation. To simulate tree-crop interaction within the SRC lines, the two double rows located in the middle of the $11 \mathrm{~m}$ row were considered pure SRC while the two double rows located on the sides were considered to interact with the crop.

\subsection{Integration of Regulation Services in a Simulation Model}

In a previous study, the Yield-SAFE model was used to model the provisioning services of the six systems in the four case-study sites [11]. For the purposes of this paper, the model was developed to integrate three RES. These were: (1) the control of soil erosion by water, (2) regulation of water quality by minimizing nitrate leaching and (3) climate regulation via sequestration of carbon in the soil and as biomass (Table 2). The methods for quantifying these regulating services are described in turn. 
Table 2. Regulating ecosystem services considered for this study following the Common International Classification of Ecosystem Services (CICES) (v5.1), the indicators used and the method implemented in the Yield Estimator for Long term Design of Silvo-arable Agro-Forestry in Europe (Yield-SAFE) model.

\begin{tabular}{|c|c|c|c|c|c|c|}
\hline \multicolumn{7}{|c|}{ Section: Regulation \& Maintenance } \\
\hline Division & Group & Class & Indicator & Method & Unit & Reference \\
\hline \multirow{3}{*}{$\begin{array}{l}\text { Regulation of physical, } \\
\text { chemical and biological } \\
\text { conditions }\end{array}$} & $\begin{array}{l}\text { Regulation of baseline } \\
\text { flows and extreme } \\
\text { events }\end{array}$ & Control of erosion rates & Soil erosion & RUSLE equation & Mg soil ha ${ }^{-1} \mathrm{yr}^{-1}$ & [22] \\
\hline & Water conditions & $\begin{array}{l}\text { Regulation of physical, } \\
\text { chemical and biological } \\
\text { conditions }\end{array}$ & Nitrate leaching & Nitrogen balance & $\mathrm{Kg} \mathrm{N} \mathrm{ha}^{-1} \mathrm{yr}^{-1}$ & [23] \\
\hline & $\begin{array}{l}\text { Atmospheric } \\
\text { composition and } \\
\text { conditions }\end{array}$ & $\begin{array}{l}\text { Regulation of chemical } \\
\text { composition of } \\
\text { atmosphere and oceans }\end{array}$ & $\begin{array}{l}\text { Carbon } \\
\text { sequestered }\end{array}$ & Yield-SAFE & $\mathrm{MgCha}{ }^{-1} \mathrm{yr}^{-1}$ & [24] \\
\hline
\end{tabular}

\subsubsection{Regulation of Soil Erosion}

The inclusion of the regulation of soil erosion within Yield-SAFE was based on the revised universal soil loss equation (RUSLE). The equation estimates long-term average annual soil loss by sheet and rill erosion and has been the most frequent model used for this purpose [22]. The RUSLE Equation (1) was implemented into the Yield-SAFE model and calculated following the approach used in Palma et al. [23] and García de Jalón et al. [25], with the exception of the cover management factor ( $C$ factor) that, for the present study, varied depending on the type and age of vegetation and on the disposition of the trees related to the crop.

$$
A=R K L S C P
$$

where $A$ is the estimated average soil loss due to water $\left(\mathrm{Mg}\right.$ soil ha $\left.{ }^{-1}\right), R$ the rainfall erosivity factor calculated over one year (in MJ mm ha ${ }^{-1}$ day $^{-1}$ ), $K$ the soil erodibility factor (in $\mathrm{Mg} \mathrm{h} \mathrm{MJ}^{-1} \mathrm{~mm}^{-1}$ ), $L S$ is the slope-length factor (unitless), $C$ the cover management factor (unitless) and $P$ the erosion-control practice factor (unitless).

The erosivity factor $(R)$ is defined as the sum of the average of the product of the kinetic energy of precipitation (erosive events) and the maximum intensity for a period of $30 \mathrm{~min}\left(\mathrm{I}_{30}\right)$. The values of $R$ for the four study sites were extracted by adding the monthly values reported in [26]. The soil erodibility factor $(K)$ is related to the susceptibility of the soil to erode and is linked to physical properties such as the organic matter content, soil texture, soil structure and permeability. The values for $K$ for the four study sites were derived from a soil erodibility map for the European Union [27]. The combined LS factor describes the effect of slope and length on soil erosion, and the value for the Portuguese, English and German study sites were extracted from the European LS factor map [28] and from Kay et al. [29] for the Swiss case study. The value of $C$ depends on land use and was dependent on the land-use scenario within each location. Depending on the type and age of the vegetation, reference values were taken from Panagos et al. [30]. A value corresponding to "forest" was considered for the $C_{\text {tree }}$ factor $\left(C_{\text {tree }}=0.03\right)$ (Table 3$)$.

Table 3. Values used for the revised universal soil loss equation (RUSLE) equation factors for the four agroforestry systems assessed.

\begin{tabular}{|c|c|c|c|c|c|c|}
\hline Factor & MONTPT & $\mathrm{CTCH}$ & SAFUK & SRCDE & Units & Reference \\
\hline$R$ & 519 & 500 & 265 & 426 & MJ mm ha ${ }^{-1}$ year $^{-1}$ & [26] \\
\hline$K$ & 0.0305 & 0.055 & 0.0305 & 0.024 & $\mathrm{th} \mathrm{MJ}^{-1} \mathrm{~mm}^{-1}$ & {$[27,29]$} \\
\hline LS & 0.3 & 0.3 & 0.3 & 0.3 & Unitless & {$[28,29]$} \\
\hline$C_{\text {tree }}$ & Cork oak: 0.03 & Cherry tree: 0.03 & Populus spp.: 0.03 & Populus spp.: 0.03 & & \\
\hline$C_{\text {crop }}$ & Iberian pastures: 0.15 & Swiss pastures: 0.15 & $\begin{array}{c}\text { Wheat: } 0.21 \\
\text { Barley: } 0.21 \\
\text { Oilseed: } 0.28\end{array}$ & $\begin{array}{c}\text { Wheat: } 0.21 \\
\text { Sugar beet: } 0.34\end{array}$ & Unitless & [30] \\
\hline$C_{\text {fallow }}$ & Fallow: 0.15 & Fallow: 0.15 & Grass: 0.15 & Grass: 0.15 & & \\
\hline$P$ & 1 & 1 & 1 & 1 & Unitless & [31] \\
\hline
\end{tabular}


For the agroforestry alternatives, the $\mathrm{C}$ factor was calculated considering the $\mathrm{C}$ factors associated with the crop $\left(C_{\text {crop }}\right)$ and the trees $\left(C_{\text {tree }}\right)$ following Palma et al. [23]. While $C_{\text {crop }}$ remained constant for a specific crop, $C_{\text {tree }}$ varied depending on the growth of the trees. For the Portuguese and Swiss traditional systems, the yearly change in the area of canopy cover was used. The tree areas in the English silvoarable and the German short rotation coppice systems were predetermined as the trees are arranged in lines and the potential canopy cover was limited. While not covered by canopies, the remaining tree area received a $C$ factor value as if it was covered by fallow $\left(C_{\text {crop }}=0.15\right)$. The final $\mathrm{C}$ factor of the system was estimated by combining the areas occupied by trees and/or crops following Equation (2):

$$
C=\left(C_{\text {crop }} * \text { Crop area }\right)+\left(C_{\text {tree }} * \text { Canopy area }\right)+\left(C_{\text {fallow (or pastures })} *(\text { Tree area }- \text { Canopy area })\right)
$$

The $P$ factor in the RUSLE equations relates to erosion-control practices and was assumed to equal 1 in each system as no additional erosion-control practices were reported.

\subsubsection{Regulation of Nitrate Leaching}

The approach suggested by Palma et al. [23] for assessing the nitrate leached was followed and implemented into the Yield-SAFE model. In this approach, the estimated nitrate leached annually $\left(\mathrm{kg} \mathrm{N} \mathrm{ha}^{-1} \mathrm{yr}^{-1}\right)$ depended on the nitrogen balance, the water flow to groundwater and the soil water content at field capacity. The potential inputs to the nitrogen balance were fertilization, atmospheric deposition, biotic fixation and mineralization. The potential nitrogen outputs were the processes of denitrification, volatilization, crop and tree uptake and immobilization.

The quantity of nitrate leached was estimated as:

$$
N_{\text {leach }}=4.43 N_{\text {bal }} E F
$$

where $N_{\text {leach }}$ is the nitrogen leached $\left(\mathrm{kg} \mathrm{N} \mathrm{ha}^{-1} \mathrm{yr}^{-1}\right), N_{\text {bal }}$ is the nitrogen balance $\left(\mathrm{kg} \mathrm{N} \mathrm{ha}^{-1} \mathrm{yr}^{-1}\right)$ and $E F$ is the annual soil water exchange factor (unitless). The value of $E F$ depended on the calculated annual flow to groundwater $\left(F_{g w}\right.$, in $\left.\mathrm{mm}\right)$ and the soil water content at field capacity $(F C$, in $\mathrm{mm})$ and is determined by the Yield-SAFE as:

$$
\begin{gathered}
\text { If } F_{g w} / F C \geq 1 \text {, then } E F=1 \\
\text { If } F_{g w} / F C<1 \text {, then } E F=F_{g w} / F C
\end{gathered}
$$

Annual values for groundwater recharge were calculated as the sum of daily estimates derived from the Yield-SAFE model. The value of the nitrogen balance $\left(N_{b a l}\right)$ was determined as:

$$
N_{b a l}=\left(N_{f e r t}+A_{\text {dep }}+N_{f i x}+N_{\text {min }}\right)-(D+V+U+I)
$$

where $N_{\text {fert }}$ is the addition of nitrogen fertilizer (mineral and organic), $A_{\text {dep }}$ is the atmospheric deposition, $N_{f i x}$ is the biotic nitrogen fixation, $N_{\min }$ is the mineralization, $D$ is the denitrification, $V$ is the volatilization, $U$ is the crop/tree nitrogen uptake and $I$ is the nitrogen immobilization (all units are in $\mathrm{kg} \mathrm{N} \mathrm{ha}^{-1} \mathrm{yr}^{-1}$ ). In long-term assessments of regular cropping rotations, the nitrogen from mineralization $\left(N_{\min }\right)$ and immobilization $(I)$ is considered to be in equilibrium and therefore is not considered in the nitrogen balance [32,33]. Although the inclusion of trees on arable land could modify this equilibrium through the additional nitrogen supplied by leaf fall or root mortality, these effects were not included in the Yield-SAFE model.

Nitrogen atmospheric deposition $\left(A_{d e p}\right)$ was obtained by summing values of oxidized and reduced nitrogen deposition from the European Monitoring and Evaluation Program [34]. $N_{f i x}$ was estimated to be $1 \mathrm{~kg} \mathrm{~N} \mathrm{ha}^{-1} \mathrm{yr}^{-1}$ [23] and an average value for denitrification $(D)$ of $30 \mathrm{~kg} \mathrm{~N} \mathrm{ha}^{-1} \mathrm{yr}^{-1}$ was considered for all the sites [23]. Volatilization $(V)$ was considered to be $5 \%$ of nitrogen fertilization 
$\left(N_{\text {fert }}\right)$ [35]. The nitrogen content of crops and trees and the amount of fertilizer per crop applied is shown in Table 4. It was considered that no extra fertilization was applied during the afforestation process and that there was no additional nitrogen input from the urine and feces of livestock.

Table 4. Nitrogen content for the crops and trees and nitrogen fertilization considered in this study.

\begin{tabular}{|c|c|c|c|c|}
\hline Crop (Units) & $\begin{array}{c}\text { N Content } \\
\text { Aboveground (0-1) }\end{array}$ & $\begin{array}{c}\text { N Content Roots } \\
(0-1)\end{array}$ & $\begin{array}{l}\text { N Fertilization Applied } \\
\left(\mathrm{kg} \mathrm{N} \mathrm{ha}^{-1} \mathrm{yr}^{-1}\right)\end{array}$ & Reference \\
\hline Montado grass & 0.02 & 0.02 & 0 & [36] \\
\hline Swiss grass & 0.03 & 0.03 & 0 & [37] \\
\hline Wheat UK & 0.022 & 0.006 & 175 & \multirow{3}{*}{ [25] } \\
\hline Barley UK & 0.01 & 0.004 & 145 & \\
\hline Oilseed UK & 0.018 & 0.007 & 200 & \\
\hline Sugar beet DE & 0.00265 & 0.00265 & 120 & [38] \\
\hline Holm oak & 0.012 & 0.0158 & 0 & [39] \\
\hline Cherry tree & 0.012 & 0.0045 & 0 & [40] \\
\hline Poplar spp. & 0.0099 & 0.004 & 0 & [41] \\
\hline
\end{tabular}

\subsubsection{Carbon Sequestration}

The capacity of the soil and above and belowground biomass to store carbon was derived using a soil carbon model (RothC, [42]) that simulates soil organic changes, integrated by Palma et al. [24] in the Yield-SAFE model. The integration included estimates of tree and crop inputs into soil, including leaf fall and root mortality. Long-life products, such as timber, were considered to store carbon, while the rapid turnover of short-life products, such as grain, cherries, sugar beet or meat (estimated through grass growth) meant that they were not included. For the silvopastoral systems (montado and Swiss orchards), the excrements of the potential livestock grazing were considered to be organic input material for the soil model. A carrying capacity of 0.5 and 1 livestock units (LU) were considered for the Portuguese and Swiss silvopastoral systems respectively, whereas carbon in excrements was estimated as $0.99 \mathrm{~kg} \mathrm{C} \mathrm{LU}^{-1}$ day $^{-1}$, considering a yearly undiluted excreta volume of $19.35 \mathrm{~m}^{3}$ year$^{-1}$ [43], a bulk density of $0.4 \mathrm{~kg} \mathrm{~m}^{-3}$ [44] and a carbon concentration of $0.047 \mathrm{~kg} \mathrm{C} \mathrm{kg} \mathrm{excrement}^{-1}$ [45].

\subsection{Use of the Model}

Once the model was developed, the next step was to collect the weather, soil, crop, tree and livestock input data needed for the Yield-SAFE model for each site. Weather data (daily solar radiation, minimum and maximum temperature, rainfall, relative humidity and wind speed) were extracted from the Climate Picker tool CliPick [46]. The soil texture and depth were derived from field data from the case-study sites, and management practices, such as the frequency and intensity of thinning or pruning, were determined from local experts.

The next step was to calibrate the model so that the yields of the agricultural and forest system matched measured values, as described in Crous-Duran et al. [11]. The total period of simulation was 80 years. The last step was to run the model for the different tree densities described in Section 2.1.

\section{Results}

\subsection{Soil Erosion}

At each case-study site, the lowest rates of soil erosion were associated with the greatest tree cover (Figure 1). The greatest soil erosion was predicted for the Swiss site, ranging, over 80 years, from $98 \mathrm{Mg}$ soil ha $^{-1}$ for the pure-pasture alternative (CTCH-A) to $83 \mathrm{Mg}$ soil ha $^{-1}$ for the tree-only system (CTCH-F). The Swiss agroforestry systems had intermediate values of 93.5, 90.3, 88 and $85 \mathrm{Mg}$ 
soil ha ${ }^{-1}$, corresponding to an increase in tree density equivalent to soil erosion reductions of $4 \%, 7 \%$, $10 \%$ and $13 \%$ compared to the pure-pasture alternative (CTCH-A).

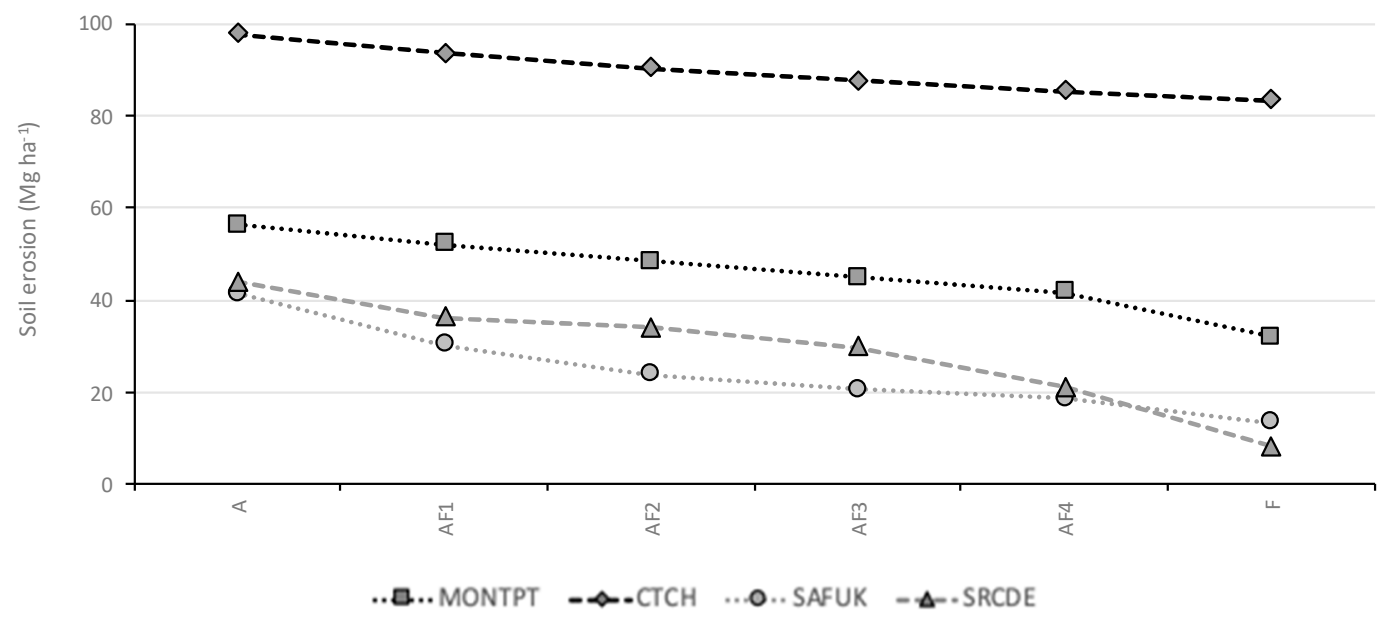

Figure 1. Accumulated soil loss for the period of 80 years (in $\mathrm{Mg}$ soil ha ${ }^{-1}$ ) for six different management alternatives in increasing tree densities across Europe for the systems in Portugal (MONTPT), Switzerland (CTCH), the UK (SAFUK) and Germany (SRCDE). MONTPT: 0 trees ha ${ }^{-1}(\mathrm{~A})$, 50 trees ha ${ }^{-1}$ (AF1), 100 trees ha $^{-1}$ (AF2), 150 trees ha $^{-1}$ (AF3), 200 trees ha ${ }^{-1}$ (AF4) and forestry (F). CTCH: 0 trees ha ${ }^{-1}$ (A), 26 trees ha ${ }^{-1}$ (AF1), 52 trees ha ${ }^{-1}$ (AF2), 78 trees ha ${ }^{-1}$ (AF3), 104 trees ha $^{-1}$ (AF4) and forestry (F). SAFUK: 0 trees ha ${ }^{-1}$ (A), 56 trees ha $^{-1}$ (AF1), 78 trees ha ${ }^{-1}$ (AF2), 118 trees ha $^{-1}$ (AF3), 156 trees ha $^{-1}$ (AF4) and forestry (F). SRCDE: pure arable (A), alley widths of $96 \mathrm{~m}$ (AF1), $72 \mathrm{~m}$ (AF2), $48 \mathrm{~m}$ (AF3), $24 \mathrm{~m}$ (AF4) and pure short rotation coppice systems (SRC) (F).

The next highest values of soil erosion occurred in the montado system, with soil losses, for the 80 -year period of simulation, ranging from $53 \mathrm{Mg}$ soil ha $^{-1}$ for the pasture system (MONTPT-A) to $33 \mathrm{Mg}$ soil ha ${ }^{-1}$ for the forest system (MONTPT-F). The presence of trees in intermediate densities reduced soil erosion by $7 \%, 14 \%, 20 \%$ and $26 \%$ in the 50 (MONTPT-AF1), 100 (MONTPT-AF2), 150 (MONTPT-AF3) and 200 trees $\mathrm{ha}^{-1}$ (MONTPT-AF4) alternatives, respectively.

In the UK, the predicted soil erosion for the period simulated ranged from $41 \mathrm{Mg} \mathrm{ha}^{-1}$ in the arable system (SAFUK-A) to $13 \mathrm{Mg} \mathrm{ha}^{-1}$ for the forestry alternative (SAFUK-F). Again, the agroforestry options led to intermediate values of $30 \mathrm{Mg} \mathrm{ha}^{-1}$ in the 39 trees ha $^{-1}$ agroforestry (SAFUK-AF1), $24 \mathrm{Mg}$ $\mathrm{ha}^{-1}$ in the 78 trees ha ${ }^{-1}$ agroforestry (SAFUK-AF2), $21 \mathrm{Mg} \mathrm{ha}^{-1}$ in the 104 trees ha ${ }^{-1}$ agroforestry (SAFUK-AF3) and $19 \mathrm{Mg} \mathrm{ha}^{-1}$ in the 154 trees ha $^{-1}$ agroforestry alternative (SAFUK-AF4). Compared to the arable alternative, these values represented a reduction of $68 \%, 27 \%, 43 \%, 50 \%$ and $55 \%$ respectively.

Finally, in Germany, the pure SRC alternative (SRCDE-F) showed a reduction of soil erosion of $82 \%$ (from 43.86 to $8.25 \mathrm{Mg}$ soil ha $^{-1}$ ) compared to a pure arable alternative (SRCDE-A); the agroforestry SRC lines reduced $17 \%, 22 \%, 32 \%$ and $51.8 \%$ if the distance between lines was $96 \mathrm{~m}$ (SRCDE-AF1), $72 \mathrm{~m}$ (SRCDE-AF2), $48 \mathrm{~m}$ (SRCDE-AF3) and $24 \mathrm{~m}$ (SRCDE-AF4), respectively.

\subsection{Nitrate Leaching}

Among the six management options, the greatest rates of nitrate leaching were predicted for arable systems in the German and the English case studies (Figure 2). Because no fertilizer was applied in the Portuguese montado and the cherry orchards systems, the rates of leaching were minimal in those systems [47].

For the silvoarable system in the UK, the presence of trees supposed a reduction of nitrate leaching cumulated after 80 years of $75 \%$, from the $2168 \mathrm{~kg} \mathrm{~N} \mathrm{ha}^{-1}$ presented in the arable alternative (SAFUK-A) to the $552,551,520$ and $487 \mathrm{~kg} \mathrm{~N} \mathrm{ha}^{-1}$ for the agroforestry alternatives (SAFUK-AF1, AF2, AF3 and AF4), respectively. Also, for this system, the nitrate leached in the forestry alternative (SAFUK-F) was also reduced by $98 \%\left(36 \mathrm{~kg} \mathrm{~N} \mathrm{ha}^{-1}\right)$ compared to the arable alternative. 
For the German system, nitrate leaching levels in the arable alternative (SRCDE-A) were higher (4726 kg N ha ${ }^{-1}$ ) compared to the agroforestry alternatives (SRCDE-AF1, AF2, AF4 and AF4) that ranged between 3885 and $2574 \mathrm{~kg} \mathrm{~N} \mathrm{ha}^{-1}$, corresponding to a reduction in nitrate leaching of $18 \%, 21 \%$, $29 \%$ and $46 \%$ if compared to arable. In the forestry alternative (SRCDE-F), the nitrate leached was nearly null (reduction of $98 \%$ ), presenting an accumulated value of $113 \mathrm{~kg} \mathrm{~N} \mathrm{ha}^{-1}$ for the 80 years simulated.

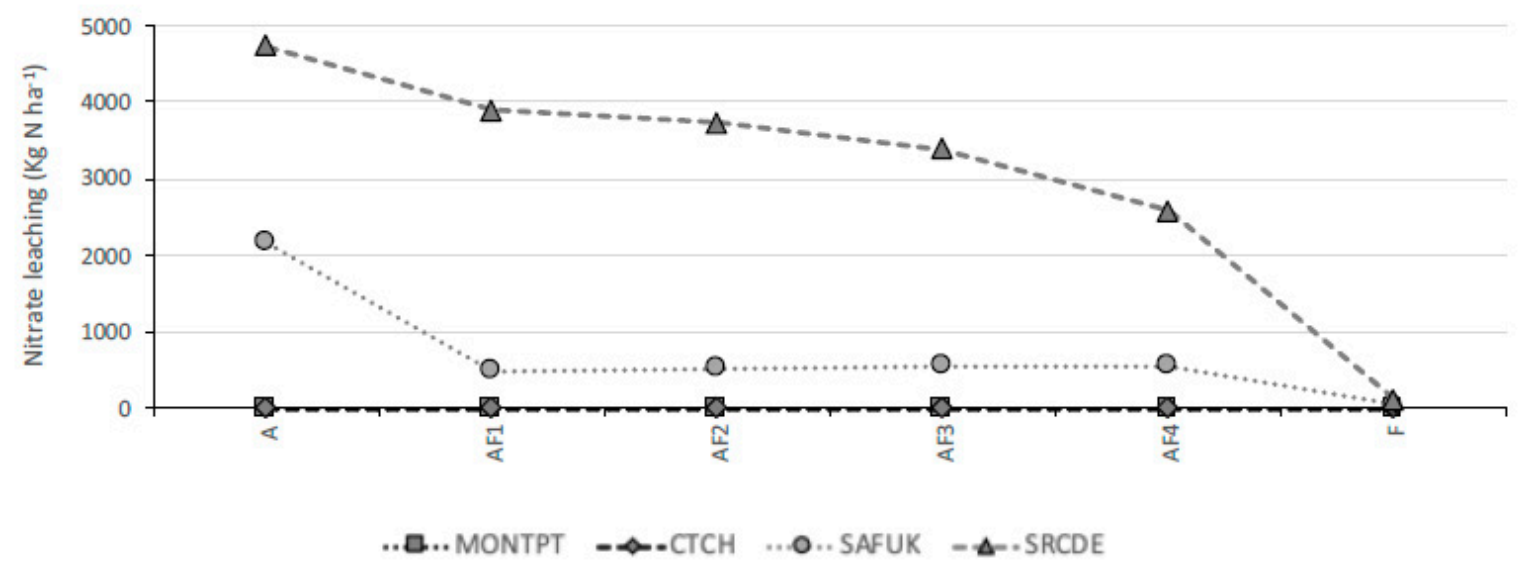

Figure 2. Accumulated nitrate leached for the period of 80 years (in $\mathrm{kg} \mathrm{N} \mathrm{ha}^{-1}$ ) for six different management alternatives in increasing tree densities across Europe for the systems in Portugal (MONTPT), Switzerland (CTCH), the UK (SAFUK) and Germany (SRCDE). MONTPT: 0 trees ha ${ }^{-1}(\mathrm{~A})$, 50 trees ha $^{-1}$ (AF1), 100 trees ha $^{-1}$ (AF2), 150 trees ha ${ }^{-1}$ (AF3), 200 trees ha ${ }^{-1}$ (AF4) and forestry (F). CTCH: 0 trees ha ${ }^{-1}$ (A), 26 trees ha ${ }^{-1}$ (AF1), 52 trees ha ${ }^{-1}$ (AF2), 78 trees ha ${ }^{-1}$ (AF3), 104 trees ha $^{-1}$ (AF4) and forestry (F). SAFUK: 0 trees ha ${ }^{-1}(\mathrm{~A}), 56$ trees ha $^{-1}$ (AF1), 78 trees ha ${ }^{-1}$ (AF2), 118 trees ha $^{-1}$ (AF3), 156 trees ha ${ }^{-1}$ (AF4) and forestry (F). SRCDE: pure arable (A), alley widths of $96 \mathrm{~m}$ (AF1), $72 \mathrm{~m}$ (AF2), $48 \mathrm{~m}$ (AF3), $24 \mathrm{~m}(\mathrm{AF} 4)$ and pure SRC (F).

\subsection{Carbon Sequestration}

The greatest levels of carbon sequestration, aggregated over 80 years, were predicted for the poplar systems in the UK (Figure 3). The predicted carbon storage in the agricultural systems remained relatively constant, ranging from an increase of $0.1 \%$ in Portugal to increase of $2.7 \%$ in Switzerland to a reduction of $5.5 \%$ in the UK and $6.0 \%$ in Germany. Across the agroforestry systems, an increase in the density of trees led to an increase in carbon storage. At the Portuguese, Swiss and British sites, the agroforestry option with the highest density of trees (MONTPT-AF4, CTCH-AF4 and SAFUK-AF4) had higher predicted levels of carbon sequestration than the forestry option. By contrast, the forestry system in Germany (SRCDE-F) was able to sequester the triple compared to the most dense agroforestry option (SRCDE-AF4).

Considering each case study, for the 80 years of assessment of the montado system, the agroforestry and forestry alternatives ranged values of carbon sequestration in total of between $24 \mathrm{Mg} \mathrm{C} \mathrm{ha-1}$ (MONTPT-AF1) and $57 \mathrm{Mg} \mathrm{C} \mathrm{ha}^{-1}$ (MONTPT-AF4). For the cherry orchards, the values ranged from $112 \mathrm{Mg} \mathrm{C} \mathrm{ha}^{-1}$ (for the CTCH-AF1 alternative) to $267 \mathrm{Mg} \mathrm{ha}^{-1}$ (found for the CTCH-AF4 and CTCH-F alternatives). In the English silvoarable system, the presence of trees allows sequestering a positive amount of up to nearly $400 \mathrm{MgC} \mathrm{ha}^{-1}$ in the most tree-dense agroforestry alternative (SAFUK-AF4) and a minimum of $240 \mathrm{Mg} \mathrm{C} \mathrm{ha}^{-1}$ in the less dense (SAFUK-AF1, 56 trees ha ${ }^{-1}$ ). These systems have a net positive carbon sequestration compared to the "no trees" alternative that shows a loss of around $1 \mathrm{MgC} \mathrm{ha}^{-1}$ (from an initial soil carbon of $21.5 \mathrm{MgC} \mathrm{ha}^{-1}$ to a final carbon sequestration of $20.5 \mathrm{Mg} \mathrm{C} \mathrm{ha}^{-1}$ ). Related to the German site, only the presence of trees ensures a positive net carbon sequestration with a minimum of $46 \mathrm{MgC} \mathrm{ha}^{-1}$ in the less dense agroforestry alternative (96 m wide lines, SRCDE-AF1) up to $122 \mathrm{Mg} \mathrm{C}^{-1}$ for the most dense agroforestry alternative (SRCDE-AF4), with the pure SRC alternative (SRCDE-F) tripling this value $\left(373 \mathrm{MgC} \mathrm{ha}^{-1}\right)$. 


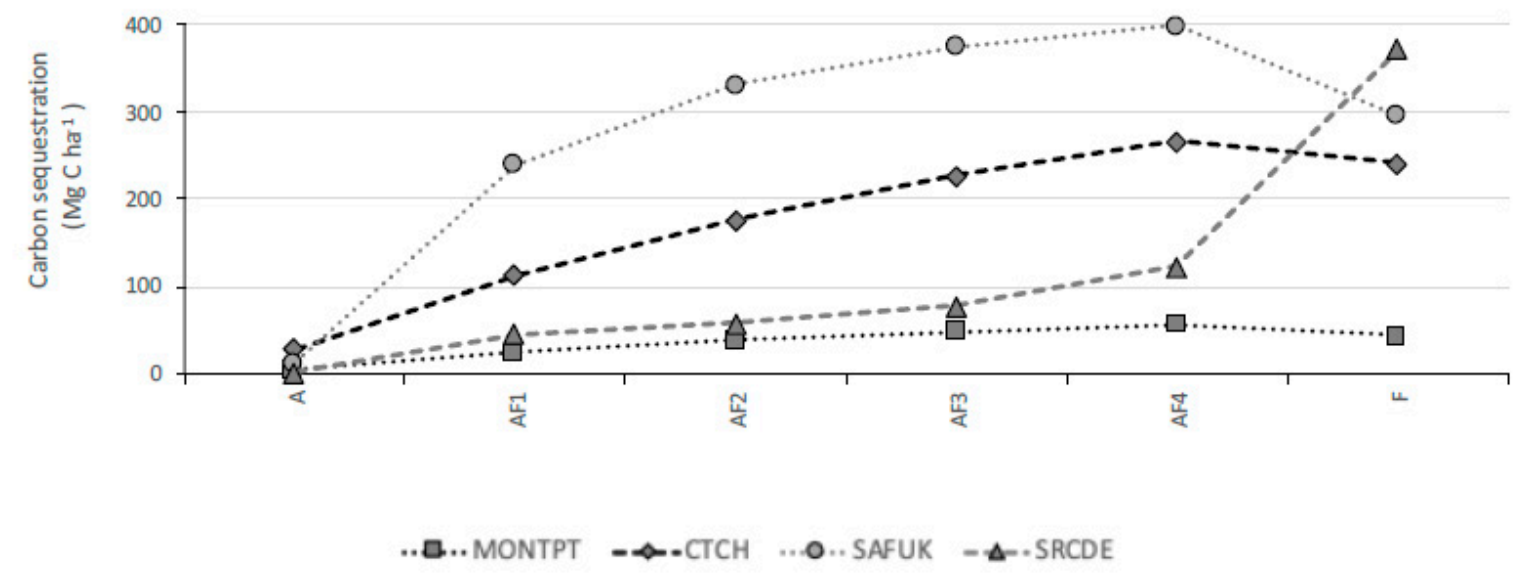

Figure 3. Carbon sequestered for the period of 80 years (in $\mathrm{Mg} \mathrm{C} \mathrm{ha}^{-1}$ ) for six different management alternatives in increasing tree densities across Europe for the systems in Portugal (MONTPT), Switzerland (CTCH), the UK (SAFUK) and Germany (SRCDE). MONTPT: 0 trees ha ${ }^{-1}(\mathrm{~A}), 50$ trees $\mathrm{ha}^{-1}$ (AF1), 100 trees ha $^{-1}$ (AF2), 150 trees ha $^{-1}$ (AF3), 200 trees ha $^{-1}$ (AF4) and forestry (F). CTCH: 0 trees ha ${ }^{-1}(\mathrm{~A}), 26$ trees ha ${ }^{-1}$ (AF1), 52 trees ha ${ }^{-1}$ (AF2), 78 trees ha ${ }^{-1}$ (AF3), 104 trees ha ${ }^{-1}$ (AF4) and forestry (F). SAFUK: 0 trees ha ${ }^{-1}$ (A), 56 trees ha ${ }^{-1}$ (AF1), 78 trees ha ${ }^{-1}$ (AF2), 118 trees ha ${ }^{-1}$ (AF3), 156 trees ha ${ }^{-1}(\mathrm{AF} 4)$ and forestry $(\mathrm{F})$.

\section{Discussion}

The results are discussed in terms of the effect of tree density on soil erosion, nitrate leaching and carbon sequestration.

\subsection{Soil Erosion}

The lowest predicted levels of soil erosion, over 80 years, ranged from $85 \mathrm{Mg} \mathrm{ha}^{-1}$ at the Swiss site and $33 \mathrm{Mg} \mathrm{ha}^{-1}$ in Portugal to $13 \mathrm{Mg} \mathrm{ha}^{-1}$ and $8 \mathrm{Mg} \mathrm{ha}^{-1}$ at the British and German sites, respectively. The low rates at the British and German sites were partly the result of low rain erosivity $(R)$ as rainfall tends to regularly be distributed through the year; at the Portuguese and the Swiss sites, much of the rainfall is concentrated into just a few months. The particularly high values at the Swiss case study site were then mostly as a result of the high soil erodibility $(K)$ [48].

Across the four case studies, a greater presence of trees, modeled through the effect of cover management ( $C$ factor), led to a predicted reduction in the rate of soil erosion (Figure 1). The value of the $\mathrm{C}$ factor is defined as how the tree and crop elements are able to mitigate soil loss compared to bare fallow areas. Because the $\mathrm{C}$ value of 0.15 for natural grasslands in Portugal or Switzerland is close to the value for tree cover (0.03), the effect of trees on avoiding soil erosion is minimized. By contrast, the high $C$ values assumed for cereals $(C=0.21)$ and sugar beet $(C=0.34)$ in the UK or Germany increases the importance of trees in reducing soil losses.

Expressed as an annual value, the soil erosion rates in Switzerland ranged from 1.03 to $1.20 \mathrm{Mg}$ soil ha ${ }^{-1}$. These rates are lower than a previously cited value of 1.8 to $2.5 \mathrm{Mg}$ soil ha $\mathrm{ha}^{-1} \mathrm{yr}^{-1}$ [29]. The difference is probably due to the high difference slopes presented in both studies and not necessarily due to a tree effect on erosion. The predicted annual soil erosion rates for the montado ranged from 0.41 to $0.66 \mathrm{Mg} \mathrm{ha}^{-1}$, similar to the values of 0.5 and $1 \mathrm{Mg}$ soil ha ${ }^{-1}$ reported by $[49,50]$. For the silvoarable systems in the UK, the annual results of 0.15 to $0.51 \mathrm{Mg} \mathrm{ha}^{-1}$ seem to be consistent, even if slightly lower compared to the values of 0.19 to $0.38 \mathrm{Mg} \mathrm{ha}^{-1}$ reported by [25]. Finally, in Germany, the annual soil erosion values estimated ranged from 0.85 to $0.20 \mathrm{Mg} \mathrm{ha}^{-1}$ soil $\mathrm{yr}^{-1}$. On moderate slopes $(\leq 5 \%)$ under SRC systems, values of erosion rates expected would be, on average, around $2 \mathrm{Mg} \mathrm{ha}^{-1}$ soil yr$^{-1}$ but the rate depends on site preparation and harvesting technology [51]. However, the lower values obtained in the present study could be explained by (1) the presence of crops in between lines that, 
as has been stated, can help reducing soil erosion [52] and (2) the reduction of the soil erodibility factor ( $\mathrm{K}$ factor) associated with the tree barrier effect that reduces evapotranspiration and increases carbon storage [53], and that was not considered in this study.

\subsection{Nitrate Leaching}

The predicted rates of nitrate leaching were driven by (1) the surplus in balance between the nitrogen inputs and outputs and (2) soil water surplus acting as the movement vector for nitrate percolation. Palma et al. [47] and Kay et al. [29] suggested that nitrate leaching is low or negligible in Mediterranean areas as precipitation rarely exceeds evapotranspiration so there is a low flow of water to groundwater. In addition, in this study, the lack of any artificial nitrogen application on natural grassland in the Portuguese case study meant that no nitrate leaching was predicted. Similarly, although the precipitation was high at the Swiss site, the lack of fertilization of the grasslands or cherry trees meant again that nitrate leaching was negligible

By contrast, in the silvoarable site in the UK, after 80 years, the predicted rate of nitrogen leaching in the agroforestry alternatives was only $22-25 \%$ of that predicted for the arable system. This was partly due to a reduced rate of nitrogen application and the deep roots of the trees taking up some of the surplus nitrogen. Expressed as an annual value, the leaching loss in the agroforestry system of around $27 \mathrm{~kg} \mathrm{~N} \mathrm{ha}^{-1}$ is similar to the value of $25 \mathrm{~kg} \mathrm{~N} \mathrm{ha}^{-1}$ reported by García de Jalón et al. [25]. Existing studies [54] have demonstrated that poplars can reduce nitrate leaching to the groundwater of agricultural landscapes. In the German case study, the predicted effect of the trees was to reduce the amount of nitrate leached but this effect was not linear as low densities are proportionally able to reduce more nitrate leaching. This effect therefore suggests that initial trees have a major reduction impact on nitrogen applied as fertilizer for growing wheat. However, no nitrate leached was appreciated in sugar beet cultivation years as it has been seen that, due to the long growing season and deep root system, sugar beet nitrogen uptake usually exceeds fertilizer application [54].

The predicted reduction in nitrate leaching due to the presence of trees is in accordance with previous studies. For example, Nair et al. [54] found a higher overall nutrient uptake in pastures with trees and therefore a lower nutrient concentration in soils. Hartmann et al. [55] reported that poplar short rotation coppice systems were more efficient in terms of nitrogen uptake when in an agroforestry system. However, the methodology used, consisting of an annual nitrogen balance between nitrogen inputs and outputs, is limited and is not able to reflect the seasonal peaks of nitrate leaching commonly associated with months with less vegetative growth or more intense rainfall events [29].

\subsection{Carbon Sequestration}

The predicted rates of carbon sequestration were derived from changes in the above- and below-ground biomass and the soil carbon content, which in turn depended on the inputs provided through root mortality and leaf fall [24]. Hence the maximum increase in carbon sequestration at each site is constrained by the biomass production. Across the four sites, the presence of additional trees increased total carbon sequestration until a point where additional trees are unable to capture more solar radiation and water [11].

For the simulation period of 80 years, the predicted carbon sequestration by the montado agroforestry systems at the dry Portuguese site ranged from $24 \mathrm{MgC} \mathrm{ha}^{-1}\left(50\right.$ trees ha $^{-1}$ ) to $57 \mathrm{Mg} \mathrm{C}$ $\mathrm{ha}^{-1}\left(200\right.$ trees ha $\left.^{-1}\right)$. This is consistent with previous studies; for example, Palma et al. [56] found values of around $40 \mathrm{MgC} \mathrm{ha}^{-1}$ for 50 trees $\mathrm{ha}^{-1}$. In the Swiss case study, the agroforestry system with 104 trees ha ${ }^{-1}$ was predicted to sequester $267 \mathrm{Mg} \mathrm{C} \mathrm{ha}^{-1}$, similar to the value of $260 \mathrm{Mg} \mathrm{C} \mathrm{ha}^{-1}$ (80 years multiplied by 3.25 Mg C ha-1 $\mathrm{yr}^{-1}$ ) reported by Kay et al. [29]. For the English silvoarable alternative of 156 trees ha ${ }^{-1}$ (SAFUK-AF4), after 20 years a tree timber growth of around $0.8 \mathrm{~m}^{3}$ tree was expected [11]. Considering a wood density for poplar of $410 \mathrm{~kg} \mathrm{~m}^{-3}$, a carbon content of $49.8 \%$ of the biomass [57] and a tree density of 156 trees ha $^{-1}$, a value around $25 \mathrm{MgC} \mathrm{ha}^{-1}$ can be estimated. Considering just timber, the results are similar to those reported by Palma et al. [48], of between 10 and 
$48 \mathrm{Mg} \mathrm{C} \mathrm{ha}^{-1}$, for a similar silvoarable system in the Netherlands when adapted to a 20-year rotation and those reported by Garcia de Jalón et al. [25] that estimated a carbon content for timber of around $22 \mathrm{Mg} \mathrm{C} \mathrm{ha}{ }^{-1}$. However, in this last value, and accounting for $30 \%$ of biomass being branches and leaves, $40 \%$ of total aboveground biomass as roots and $20 \mathrm{Mg} \mathrm{C} \mathrm{ha}^{-1}$ of initial soil carbon, the total amount adds up to $68 \mathrm{MgC} \mathrm{ha}^{-1}$ accumulated per rotation (20 years).

Crous-Duran et al. [11] calibrated the Yield-SAFE model for the German short rotation coppice system. With a final tree density of 7157 trees $^{-1}{ }^{-1}$, for a 4 -year rotation, the average value was $4.9 \mathrm{~kg}$ tree $^{-1}$, corresponding to a total stand biomass of $33 \mathrm{Mg} \mathrm{ha}^{-1}$. A similar system with approximate yields is reported by Mirck et al. [58] and Kanzler and Mirck [59], although with a stand density starting at 8497 trees ha $^{-1}$ and a final density of 6295 tree ha $^{-1}$. These authors reported an average tree biomass of $3.59 \mathrm{~kg}$ tree $\mathrm{e}^{-1}$ and a total stand biomass yield of $22.6 \mathrm{Mg} \mathrm{ha}^{-1}$. Considering a carbon content in poplar of $50 \%$ of the total biomass [57], our results show levels of carbon sequestered in aboveground biomass averaging $16.5 \mathrm{Mg} \mathrm{C} \mathrm{ha}^{-1}$. On the other hand, for this system, soil carbon levels remained nearly constant in all the alternatives analyzed in accordance with the previously found non-significance in soil organic carbon in SRC plantations compared to adjacent crop fields [60].

\subsection{Relative Effect of Additional Trees}

Within the Yield-SAFE model, the predicted soil erosion, nitrate leaching and carbon sequestration within agroforestry systems are dependent on the growth of the tree and crop elements. In general, the higher canopy and deeper rooting of trees, relative to grass and arable crops, meant that biomass production within the system increased as tree density increased.

At each site, the lowest rate of soil erosion was observed in the system with the highest tree density. However, at the Portuguese, Swiss and British sites (where the densest agroforestry system had the same tree density as the tree-only system), the tree-only system had a lower predicted rate of soil erosion.

Comparing the tree-present alternatives to the arable alternative and considering the average decrease in soil erosion avoided, results show that the initial trees are able to avoid more soil erosion compared to the additional ones (Figure 4A). In this sense, the increase in tree density from A to AF1 represents an average decrease of $14 \%$ of the soil erosion while the following increases in tree density (AF2, AF3 and AF4) just represent a decrease of 7.7\%, 6.5\% and $8.1 \%$ of soil eroded, respectively.

Related to the nitrate leaching, as the Portuguese montado and the Swiss cherry orchards do not present fertilization of the grasslands, nitrate leaching was considered negligible for these systems. For the English silvoarable and the German short rotation case studies, the forestry alternatives (SAFUK-F and SRCDE-F) are able to nearly eliminate any trace of nitrate leaching (99\% and $98 \%$, respectively). However, there is a difference between both systems related to the effect of the implementation of the first trees. In this sense, the AF1 alternative for the English case (SAFUK-AF1) is able to reduce $78 \%$ of the nitrate leaching while, in the German case, the reduction is only of $18 \%$, reaching $46 \%$ for the most dense agroforestry alternative (SRCDE-AF4). Both values are within the range previously observed of between $40 \%$ and $70 \%$ [3,4,54] and up to $85 \%$ in greenhouse experiments [61].

Finally, in relation to the carbon sequestration in all the four systems, the arable alternatives are considered to be in equilibrium and present a null or even a slightly decreased capacity to sequester carbon after 80 years of simulation. Also, the AF4 alternatives perform better than the forestry alternatives in the Portuguese montado (MONTPT-AF4), the Swiss orchards (CTCH-AF4) and the silvoarable systems in the UK (SAFUK-AF4). The forestry alternative has higher performance in the German short rotation site. However, again, for the four systems, an "initial tree effect" is detected, meaning that the initial trees have a higher impact in terms of carbon sequestered in biomass and soil compared to the following ones with increases on average of $92 \mathrm{Mg} \mathrm{C} \mathrm{ha}^{-1}$. This effect is very important for the silvoarable system in the UK, where the less tree-dense alternative (SAFUK-AF1) is able to sequester an additional $227 \mathrm{MgC} \mathrm{ha}^{-1}$ compared to the arable alternative (SAFUK-A). 
A

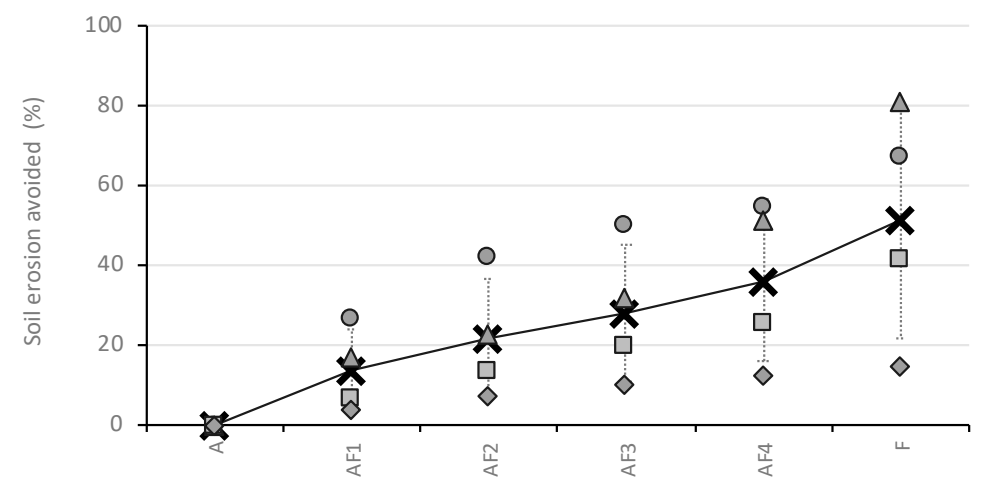

B
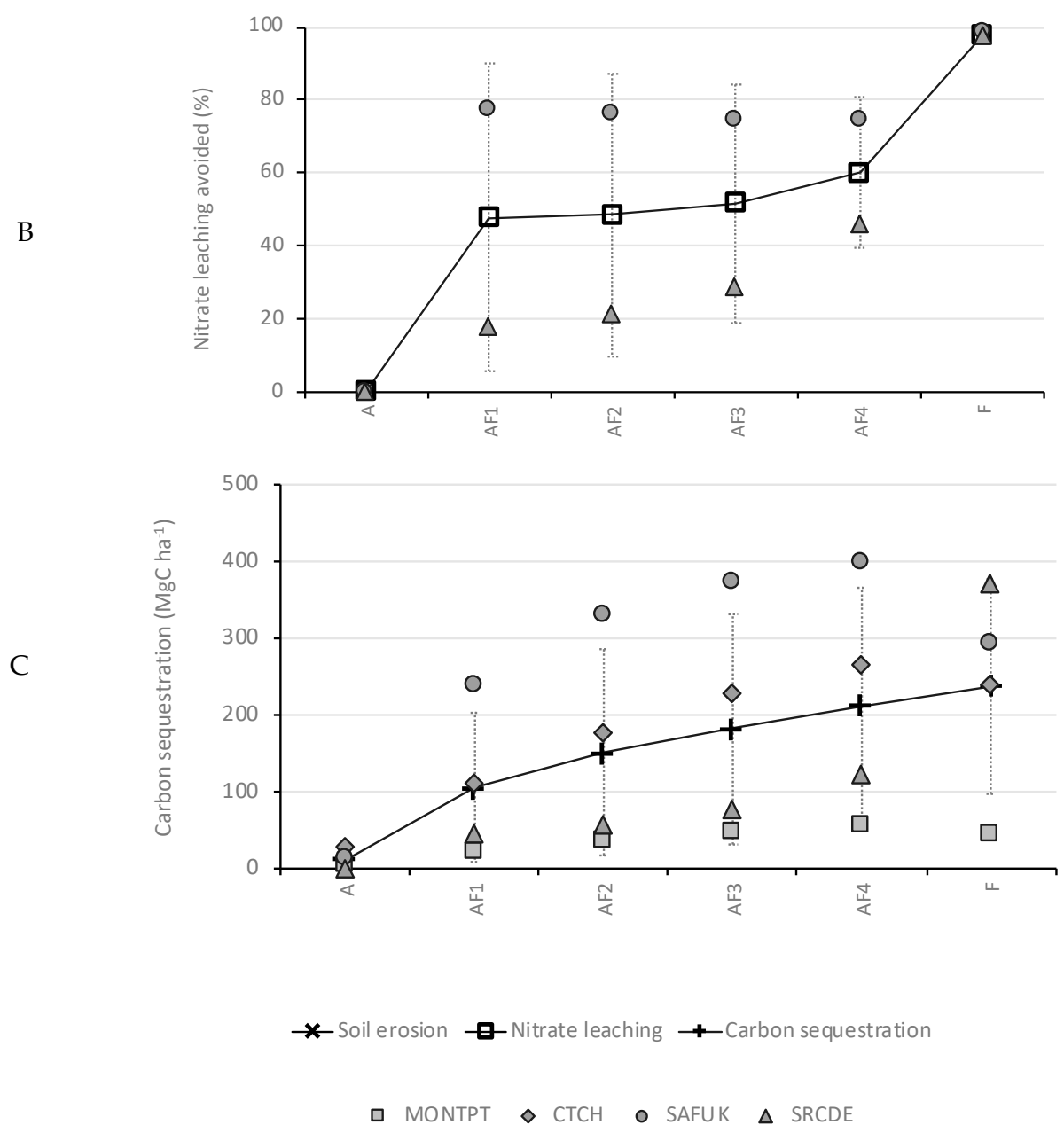

Figure 4. Average percentage of reduction of soil loss (A), average percentage of reduction of nitrate leaching (B) and average percentage of increase in carbon sequestration (C) for six different management alternatives in increasing tree densities across Europe: for the montado systems in Portugal (MONTPT), the cherry orchards in Switzerland (CTCH), the silvoarable systems in the UK (SAFUK) and the short rotation coppice in Germany (SRCDE). MONTPT: 0 trees ha ${ }^{-1}(\mathrm{~A}), 50$ trees ha ${ }^{-1}$ (AF1), 100 trees ha $^{-1}$ (AF2), 150 trees ha $^{-1}$ (AF3), 200 trees ha $^{-1}$ (AF4) and forestry (F). CTCH: 0 trees ha ${ }^{-1}(\mathrm{~A}), 26$ trees $\mathrm{ha}^{-1}$ (AF1), 52 trees ha ${ }^{-1}$ (AF2), 78 trees ha ${ }^{-1}$ (AF3), 104 trees ha ${ }^{-1}$ (AF4) and forestry (F). SAFUK: 0 trees ha ${ }^{-1}$ (A), 56 trees ha ${ }^{-1}$ (AF1), 78 trees ha ${ }^{-1}$ (AF2), 117 trees ha $^{-1}$ (AF3), 156 trees ha $^{-1}$ (AF4) and forestry (F). SRCDE: 0 trees ha ${ }^{-1}$ (A), alley widths of $96 \mathrm{~m}$ (AF1), $72 \mathrm{~m}$ (AF2), $48 \mathrm{~m}$ (AF3), $24 \mathrm{~m}$ (AF4) and pure SRC $(\mathrm{F})$. 


\subsection{Link to Provisioning Services}

Crous-Duran et al. [11] showed that an increase in the tree density was associated with an increase in the amount of energy accumulated by the different alternatives and quantified as provisioning ecosystem services (PES, food, materials and energy) but also that the accumulated energy per tree was reduced as tree density increased. For all the alternatives, the energy accumulated per tree was greatest in the lowest tree densities alternative (AF1, 50 trees ha $^{-1}$ for the Portuguese montado, 26 trees $\mathrm{ha}^{-1}$ for the Swiss cherry orchards, 56 trees ha ${ }^{-1}$ for the English silvoarable systems and $96 \mathrm{~m}$ alley widths for the German SRC system). The results were explained by the concept that the combined presence of trees and crops in the same parcel help to better use the natural resources available (soil, water and light) by both elements. However, increasing the tree density was also associated with an increase in the tree interspecific competition that leads to a reduction of the biomass stored by each tree $[1,62]$. In the present study, as the methodologies implemented are related directly to tree and crop element growth, results become consistent. In general, all the systems present a higher capacity to mediate soil erosion and nitrate leaching and sequester carbon as tree density increases, meaning that the combination in the same area of trees and crops increases not just the supply of food, energy and materials but also the capacity of the system to regulate the environment. However, both effects, if allocated to each tree, decrease as more trees are added into the field. Therefore, the potential of trees to act as suppliers of goods and regulators of the ecosystem conditions is different depending on the total number of trees already present in the system. Tree density also plays an important role as the growth rate has an effect on the amount and rate of the RES supplied, especially when there is a reduction in individual tree growth associated with an increase in tree density [11,63]. This growth rate is also affected by other aspects that need to be considered for a better understanding of the magnitude and direction of the beneficial effects supplied. These aspects can be related to weather and soil conditions of the locations of the systems, the tree and crop varieties selected or the distribution of both in the fields. In this sense, the holm oak can be considered a slow-growing tree species, needing around 80 years before being considered mature. Cherry trees are intermediate, with 40 to 60 years until tree harvest and the poplar varieties used in the English silvoarable system and the German bioenergy system offer much shorter rotations: 20 years in the UK and 12 years (three rotations of 4 years each) in the German case study. For the supply of environmental benefits, the time needed for the positive effects to become noticeable would be different.

Another aspect to consider is that the inclusion of woody elements in farmland in agroforestry systems helps storing carbon in (a) long-term biomass compared to no-tree systems but also in (b) the soil [64]. The inclusion of tree elements increases storage compared to no-tree alternatives and the rate of sequestration increases as tree elements grow [65]. However, an important point of discussion is the life expectancy of the carbon sink present in this biomass and in the wood products associated. Carbon stored after harvest in SRC systems can be considered as very short (around 1-3 years) or short for poplar cheap wood (5-10 years); the carbon stored in wood used in furniture (as expected for the cherry tree wood) will be stored for decades and, if trees are not harvested, storage can even be endured for even centuries. In this study, the potential carbon sequestered by the biomass grown by the systems is estimated, but the final destination of this biomass should be considered for a better perception of the potential capacity of these systems to have an impact on the reduction of the GHG emissions and on mitigating climate change.

Finally, when considering how tree density affects the overall biomass growth of a system and the related capacity to mediate the biophysical conditions, there is a need to consider the microclimatic effects associated with the tree canopy cover presence. Currently, the Yield-SAFE model considers competition between trees and crops for water and light and does not include the capacity of trees to grow deeper roots or increase height or leaf area in case of intraspecific competition. The assessment presented does not consider the potential modification of air temperature and wind speed and the consequent effects on the vapor pressure deficits or soil water due to the canopy presence that can have an impact on the productivity of the elements [66-68]. During the AGFORWARD project, 
recent research included the implementation of these microclimatic effects due to tree presence into the Yield-SAFE model [69]; however, the consequences for the potential supply of provisioning or regulating ecosystem services have not been tested and should be considered in future research.

\section{Conclusions}

Environmental benefits offered by four agroforestry systems in different biogeographical conditions are assessed, comparing the results with no-tree and high tree density alternatives, allowing a better understanding of the role played by trees in arable land. Considering the limited information and quality of data available for comparison and the restrictions derived from the implementation process of the methodologies to Yield-SAFE, the results of this integrated analysis show an increase in the regulation and maintenance of ecosystem services. The results of this integrated analysis show an increase in the regulation and maintenance of ecosystem services in air, soil and water compartments related to tree density. In this sense, an increase in tree density resulted in (1) a maintenance of the soil structure and quality as trees act as agents avoiding soil erosion due to the presence of the canopy and permanent grass cover in the tree line in the case of linear systems, (2) an increase in the water quality as trees uptake the excess of nutrients needed in farming practices (recovery factor of nutrients is usually never above 0.8 [70-72]) and (3) a reduction of the amount of GHG in the atmosphere as the systems are able to sequester more carbon in biomass and soil. However, similarly to the assessment made of provisioning ecosystem services [11], the effects are not linear. On one hand, the value of lower tree densities is a strong boost in regulating services; on the other hand, lower tree densities have higher incremental value, comparatively, than higher tree densities.

In any case, what this study assessed was whether the introduction of trees in arable land can potentially bring, in addition to an increase in the supply of provisioning ecosystem services shown in a previous study [11] and by benefiting from the better use of the natural resources available (soil, water and light) between trees and crops, an improvement in the supply of regulating ecosystem services, i.e., the potential capacity of the system to regulate the environment and reduce soil erosion and the nitrate leached and increasing the amount of carbon sequestered. This is a win-win situation that, if well managed, can converge a financial benefit for the landowner and an environmental/societal benefit for the general public, reinforcing the concept of agroforestry as a valuable sustainable intensification practice.

Author Contributions: Concept, J.C.-D. and J.H.N.P.; methodology, J.C.-D., A.R.G., S.G.d.J. and J.H.N.P.; formal analysis, J.C.-D. and J.H.N.P.; original draft preparation, J.C.-D., J.H.N.P. and S.G.d.J.; writing-review and editing, J.C.-D., J.H.N.P., P.J.B., S.G.d.J., S.K., M.T., A.R.G. and M.G.; funding acquisition, P.J.B., M.T. and J.H.N.P. All authors have read and agreed to the published version of the manuscript.

Funding: We acknowledge the financial support provided by the Portuguese Foundation for Science and Technology (FCT) through the scholarship (SFRH/BD/52691/2014) and the European Community's Seventh Framework Programme under Grant Agreement No. 613520 (Project AGFORWARD). This research was funded by the Forest Research Centre, a research unit funded by Fundação para a Ciência e a Tecnologia I.P. (FCT), Portugal (UIDB/00239/2020).

Conflicts of Interest: The authors declare no conflict of interest.

\section{Abbreviations}

$\begin{array}{ll}\text { AFS } & \text { Agroforestry systems } \\ \text { CICES } & \text { Common International Classification of Ecosystem Services } \\ \text { CTCH } & \text { Cherry tree pastures in Switzerland } \\ \text { MONTPT } & \text { Montado in Portugal (MONTPT) } \\ \text { SAFUK } & \text { Silvoarable systems in the United Kingdom } \\ \text { SRCDE } & \text { Short rotation coppice systems in Germany } \\ \text { PES } & \text { Provisioning ecosystem services } \\ \text { RES } & \text { Regulating ecosystem services } \\ \text { RUSLE } & \text { Revised universal soil loss equation }\end{array}$




\section{References}

1. Graves, A.R.; Burgess, P.J.; Palma, J.H.N.; Herzog, F.; Moreno, G.; Bertomeu, M.; Dupraz, C.; Liagre, F.; Keesman, K.; van der Werf, W.; et al. Development and application of bio-economic modelling to compare silvoarable, arable, and forestry systems in three European countries. Ecol. Eng. 2007, 29, 434-449. [CrossRef]

2. Cannell, M.G.R.; Noordwijk, M.; Ong, C.K. The central agroforestry hypothesis: The trees must acquire resources that the crop would not otherwise acquire. Agrofor. Syst. 1996, 34, 27-31. [CrossRef]

3. Nair, P.K.R. The coming of age of agroforestry. J. Sci. Food Agric. 2007, 87, 1613-1619. [CrossRef]

4. Jose, S. Agroforestry for ecosystem services and environmental benefits: An overview. Agrofor. Syst. 2009, 76,1-10. [CrossRef]

5. Godfray, H.C.J.; Beddington, J.R.; Crute, I.R.; Haddad, L.; Lawrence, D.; Muir, J.F.; Pretty, J.; Robinson, S.; Thomas, S.M.; Toulmin, C. Food Security: The Challenge of Feeding 9 billion. Science 2012, 327, 812-818. [CrossRef]

6. Klaa, K.; Mill, P.J.; Incoll, L.D. Distribution of small mammals in an silvorable agroforestry system in Northern England. Agrofor. Syst. 2005, 63, 101-110. [CrossRef]

7. Cardinael, R.; Chevallier, T.; Barthès, B.G.; Saby, N.P.A.; Parent, T.; Dupraz, C.; Bernoux, M.; Chenu, C. Impact of alley cropping agroforestry on stocks, forms and spatial distribution of soil organic carbon-A case study in a Mediterranean context. Geoderma 2015, 259-260, 288-299. [CrossRef]

8. Moreno, G.; Aviron, S.; Berg, S.; Crous-Duran, J.; Franca, A.; García de Jalón, S.; Hartel, T.; Mirck, J.; Pantera, A.; Palma, J.H.N.; et al. Agroforestry systems of high nature and cultural value in Europe: Provision of commercial goods and other ecosystem services. Agrofor. Syst. 2017. [CrossRef]

9. Burgess, P.J.; Rosati, A. Advances in European agroforestry: Results from the AGFORWARD project. Agrofor. Syst. 2018, 92, 801-810. [CrossRef]

10. Van der Werf, W.; Keesman, K.; Burgess, P.; Graves, A.; Pilbeam, D.; Incoll, L.D.D.; Metselaar, K.; Mayus, M.; Stappers, R.; van Keulen, H.; et al. Yield-SAFE: A parameter-sparse, process-based dynamic model for predicting resource capture, growth, and production in agroforestry systems. Ecol. Eng. 2007, 29, 419-433. [CrossRef]

11. Crous-Duran, J.; Graves, A.R.; Paulo, J.A.; Mirck, J.; Oliveira, T.S.; Kay, S.; García de Jalón, S.; Palma, J.H.N. Modelling tree density effects on provisioning ecosystem services in Europe. Agrofor. Syst. 2019, 93, 1985-2007. [CrossRef]

12. García de Jalón, S.; Graves, A.; Moreno, G.; Palma, J.H.N.; Crous-Duran, J.; Kay, S.; Burgess, P.J. Forage-SAFE: A model for assessing the impact of tree cover on wood pasture profitability. Ecol. Model. 2018, 372, $24-32$. [CrossRef]

13. Pinto-Correia, T. Threatened landscape in Alentejo, Portugal: The "montado" and other "agro-silvo-pastoral" systems. Landsc. Urban Plan. 1993, 24, 43-48. [CrossRef]

14. Pinto-Correia, T.; Ribeiro, N.; Sá-Sousa, P. Introducing the montado, the cork and holm oak agroforestry system of Southern Portugal. Agrofor. Syst. 2011, 82, 99-104. [CrossRef]

15. Olea, L.; San Miguel-Ayanz, A. The Spanish dehesa. A traditional Mediterranean silvopastoral system linking production and nature conservation. In Sustainable Grassland Productivity, Proceedings of the 21st General Meeting of the European Grassland Federation, Badajoz, Spain, 3-6 April 2006; Organizing Committee of the 21st General Meeting of the European Grassland Federation: Madrid, Spain, 2006; pp. 3-13.

16. Sereke, F.; Graves, A.; Dux, D.; Palma, J.; Herzog, F. Innovative agroecosystem goods and services: Key profitability drivers in Swiss agroforestry. Agron. Sustain. Dev. 2015, 35, 759-770. [CrossRef]

17. Eichhorn, M.P.; Paris, P.; Herzog, F.; Incoll, L.D.; Liagre, F.; Mantzanas, K.; Mayus, M.; Moreno, G.; Papanastasis, V.P.; Pilbeam, D.J.; et al. Silvoarable systems in Europe-Past, present and future prospects. Agrofor. Syst. 2006, 67, 29-50. [CrossRef]

18. Herzog, F. Streuobst: A traditional agroforestry system as a model for agroforestry development in temperate Europe. Agrofor. Syst. 1998, 42, 61-80. [CrossRef]

19. Burgess, P.J.; Incoll, L.D.; Corry, D.T.; Beaton, A.; Hart, B.J. Poplar (Populus spp) growth and crop yields in a silvoarable experiment at three lowland sites in England. Agrofor. Syst. 2005, 63, 157-169. [CrossRef]

20. Becker, A.; Kemnitz, D.; Peters, D. Erhebung, Aufbereitung und Analyse Statistischer Daten zum Anbau und zur Verarbeitung Nachwachsender Rohstoffe und Energiepflanzen in Deutschland sowie Weiterentwicklung von Methoden Hierzu; Fachagentur Nachwachsende Rohstoffe: Gülzow-Prüzen, Germany, 2019. 
21. Manning, D.B.; Bemmann, A.; Bredemeier, M.; Lamersdorf, N.; Ammer, C. Bioenergy from Dendromass for the Sustainable Development of Rural Areas; Butler Manning, D., Bemmann, A., Bredemeier, M., Lamersdorf, N., Ammer, C., Eds.; Wiley-VCH: Weinheim, Germany, 2015; ISBN 9783527682973.

22. Panagos, P.; Borrelli, P.; Poesen, J.; Ballabio, C.; Lugato, E.; Meusburger, K.; Montanarella, L.; Alewell, C. The new assessment of soil loss by water erosion in Europe. Environ. Sci. Policy 2015, 54, 438-447. [CrossRef]

23. Palma, J.H.N.; Graves, A.R.; Burgess, P.J.; Keesman, K.J.; van Keulen, H.; Mayus, M.; Reisner, Y.; Herzog, F. Methodological approach for the assessment of environmental effects of agroforestry at the landscape scale. Ecol. Eng. 2007, 29, 450-462. [CrossRef]

24. Palma, J.H.N.; Crous-Duran, J.; Graves, A.R.; Garcia de Jalón, S.; Upson, M.; Oliveira, T.S.; Paulo, J.A.; Ferreiro-Dominguez, N.; Moreno, G.; Burgess, P.J. Integrating belowground carbon dynamics into Yield-SAFE, a parameter sparse agroforestry model. Agrofor. Syst. 2017, 92, 1047-1057. [CrossRef]

25. García de Jalón, S.; Graves, A.R.; Palma, J.H.N.; Williams, A.; Upson, M.; Burgess, P.J. Modelling and valuing the environmental impacts of arable, forestry and agroforestry systems: A case study. Agrofor. Syst. 2018, 92, 1059-1073. [CrossRef]

26. Ballabio, C.; Borrelli, P.; Spinoni, J.; Meusburger, K.; Michaelides, S.; Beguería, S.; Klik, A.; Petan, S.; Janeček, M.; Olsen, P.; et al. Mapping monthly rainfall erosivity in Europe. Sci. Total Environ. 2017, 579, 1298-1315. [CrossRef] [PubMed]

27. Panagos, P.; Meusburger, K.; Ballabio, C.; Borrelli, P.; Alewell, C. Soil erodibility in Europe: A high-resolution dataset based on LUCAS. Sci. Total Environ. 2014, 479-480, 189-200. [CrossRef] [PubMed]

28. Panagos, P.; Borrelli, P.; Meusburger, K. A New European Slope Length and Steepness Factor (LS-Factor) for Modeling Soil Erosion by Water. Geosciences 2015, 5, 117-126. [CrossRef]

29. Kay, S.; Crous-Duran, J.; Ferreiro-Domínguez, N.; García de Jalón, S.; Graves, A.; Moreno, G.; Mosquera-Losada, M.R.; Palma, J.H.N.; Roces-Díaz, J.V.; Santiago-Freijanes, J.J.; et al. Spatial similarities between European agroforestry systems and ecosystem services at the landscape scale. Agrofor. Syst. 2018, 92, 1075-1089. [CrossRef]

30. Panagos, P.; Borrelli, P.; Meusburger, K.; Alewell, C.; Lugato, E.; Montanarella, L. Estimating the soil erosion cover-management factor at the European scale. Land Use Policy 2015, 48, 38-50. [CrossRef]

31. Panagos, P.; Borrelli, P.; Meusburger, K.; van der Zanden, E.H.; Poesen, J.; Alewell, C. Modelling the effect of support practices (P-factor) on the reduction of soil erosion by water at European scale. Environ. Sci. Policy 2015, 51, 23-34. [CrossRef]

32. Noy-Meir, I.; Harpaz, Y. Agro-ecosystems in Israel. In Agro-Ecosystems; Harper, J., Gruys, P., Eds.; Elsevier Scientific Publishing: Amsterdam, The Netherlands, 1977; pp. 143-167.

33. Vlek, P.L.G.; Fillery, I.R.P.; Burford, J.R. Accesion, transformation, and loss of nitrogen in soils of the arid region. Plant Soil 1981, 58, 133-175. [CrossRef]

34. EMEP Cooperative Programme for Monitoring and Evaluation of the Long-Range Transmission of Air Pollutants in Europe. Available online: www.emep.int (accessed on 7 April 2019).

35. Van Keulen, H.; Aarts, H.F.M.; Habekotté, B.; Van Der Meer, H.G.; Spiertz, J.H.J. Soil-plant-animal relations in nutrient cycling: The case of dairy farming system "De Marke". Eur. J. Agron. 2000, 13, 245-261. [CrossRef]

36. Otieno, D.O.O.; Mirzaei, H.; Hussain, M.Z.Z.; Li, Y.L.L.; Schmidt, M.W.T.; Wartinger, M.; Jung, E.; Ribeiro, N.; Pereira, J.S.S.; Tenhunen, J. Herbaceous layer development during spring does not deplete soil nitrogen in the Portuguese montado. J. Arid Environ. 2011, 75, 231-238. [CrossRef]

37. Büchi, L.; Gebhard, C.A.; Liebisch, F.; Sinaj, S.; Ramseier, H.; Charles, R. Accumulation of biologically fixed nitrogen by legumes cultivated as cover crops in Switzerland. Plant Soil 2015, 393, 163-175. [CrossRef]

38. Draycott, A.P. Sugar Beet; Blackwell Publishing: Oxford, UK, 2006; ISBN 9781405119115.

39. Bazot, S.; Barthes, L.; Blanot, D.; Fresneau, C. Distribution of non-structural nitrogen and carbohydrate compounds in mature oak trees in a temperate forest at four key phenological stages. Trees Struct. Funct. 2013, 27, 1023-1034. [CrossRef]

40. Morhart, C.; Sheppard, J.P.; Schuler, J.K.; Spiecker, H. Above-ground woody biomass allocation and within tree carbon and nutrient distribution of wild cherry (Prunus avium L.)—A case study. For. Ecosyst. 2016, 3, 4. [CrossRef]

41. Euring, D.; Ayegbeni, S.; Jansen, M.; Tu, J.; Gomes Da Silva, C.; Polle, A. Growth performance and nitrogen use efficiency of two Populus hybrid clones (P. nigra $\times$ P. maximowiczii and P. trichocarpa $\times$ P. maximowiczii) in relation to soil depth in a young plantation. IForest 2016, 9, 847-854. [CrossRef] 
42. Coleman, K.; Jenkinson, D.S. RothC-A model for the turnover of carbon in soil. Eval. Soil Org. Matter Model. 2014, 1-44. [CrossRef]

43. Steven, A.; Duethman, D.; Gooday, R.; Harris, D.; Newell-Price, P.; Chadwick, D.; Misselbrook, T. Quantitative Assessment of Scenarios for Managing Trade-Off Between Economics, Environment and Media; Project WQ0106; DEFRA: London, UK, 2009.

44. Agnew, J.M.; Leonard, J.J.; Feddes, J.; Feng, Y. A modified air pycnometer for compost air volume and density determination. Can. Biosyst. Eng. 2003, 45, 6-27.

45. Van Horn, H.H.; Wilkie, A.C.; Powers, W.J.; Nordstedt, R.A. Components of Dairy Manure Management Systems. J. Dairy Sci. 1994, 77, 2008-2030. [CrossRef]

46. Palma, J.H.N. Clipick-Climate change web picker. A tool bridging daily climate needs in process based modelling in forestry and agriculture. For. Syst. 2017, 26, 14. [CrossRef]

47. Palma, J.H.N.; Graves, A.R.; Bunce, R.G.H.; Burgess, P.J.; de Filippi, R.; Keesman, K.J.; van Keulen, H.; Liagre, F.; Mayus, M.; Moreno, G.; et al. Modeling environmental benefits of silvoarable agroforestry in Europe. Agric. Ecosyst. Environ. 2007, 119, 320-334. [CrossRef]

48. García-Ruiz, J.M.; Beguería, S.; Nadal-Romero, E.; González-Hidalgo, J.C.; Lana-Renault, N.; Sanjuán, Y. A meta-analysis of soil erosion rates across the world. Geomorphology 2015, 239, 160-173. [CrossRef]

49. Guerra, C.A.; Pinto-correia, T.; Metzger, M.J. Mapping Soil Erosion Prevention Using an Ecosystem Service Modeling Framework for Integrated Land Management and Policy. Ecosystems 2014, 17, 878-889. [CrossRef]

50. Pimentel, D.; Krummel, J. Biomass energy and soil erosion: Assessment of resource costs. Biomass 1987, 14, 15-38. [CrossRef]

51. Tolbert, V.; Mann, L.; Tolbert, V. Soil Sustainability in Renewable Biomass Plantings. AMBIO J. Hum. Environ. 2000, 29, 492-498. [CrossRef]

52. Kort, J.; Collins, M.; Ditsch, D. A review of soil erosion associated to biomass crops. Biomass Bioenergy 1998, 14, 351-359. [CrossRef]

53. Sylvester-Bradley, R.; Shepherd, M.A. Effects of interposing sugar beet on the nitrogen response of the following wheat crop. J. Sci. Food Agric. 1997, 74, 323-330. [CrossRef]

54. Nair, V.D.; Nair, P.K.R.; Kalmbacher, R.S.; Ezenwa, I.V. Reducing nutrient loss from farms through silvopastoral practices in coarse-textured soils of Florida, USA. Ecol. Eng. 2007, 29, 192-199. [CrossRef]

55. Hartmann, L.; Lamersdorf, N. Site Conditions, Initial Growth and Nutrient and Litter Cycling of Newly Installed Short Rotation Coppice and Agroforestry Systems. In Bioenergy from Dendromass for the Sustainable Development of Rural Areas; Butler Manning, D., Bemmann, A., Bredemeier, M., Lamersdorf, N., Ammer, C., Eds.; Wiley-VCH: Weinheim, Germany, 2015; ISBN 978-3-527-33764-4.

56. Palma, J.H.N.; Paulo, J.A.; Tomé, M. Carbon sequestration of modern Quercus suber L. silvoarable agroforestry systems in Portugal: A YieldSAFE-based estimation. Agrofor. Syst. 2014, 88, 791-801. [CrossRef]

57. Mathews, G. The Carbon Content of Trees; Forestry Commission Technical Paper 4; Forestry Commission of the United Kingdom: Edinburgh, UK, 1993.

58. Mirck, J.; Kanzler, M.; Quinkenstein, A. Agforward Project System Report: Alley Cropping in Germany. Agforward Project; BTU Cottbus-Senftenberg: Cottbus, Germany, 2016; Available online: https://www.agforward.eu/index.php/pt/integracao-de-arvores-e-culturas-arvenses-alemanha-862.html? file=files/agforward/documents/WP4\%20Initial\%20Stakeholder\%20report\%20BTU\%20Arable\%20final.pdf (accessed on 15 August 2020).

59. Kanzler, M.; Mirck, J. Lessons Learnt-Alley Cropping in Germany; Leaflet of the FP7 AGFORWARD Project; European Comission: Brussels, Belgium, 2017.

60. Medinski, T.V.; Freese, D.; Böhm, C.; Slazak, A. Soil carbon fractions in short rotation poplar and black locust coppices, Germany. Agrofor. Syst. 2014, 88, 505-515. [CrossRef]

61. López-Díaz, M.L.; Rolo, V.; Moreno, G. Trees' role in nitrogen leaching after organic, mineral fertilization: A greenhouse experiment. J. Environ. Qual. 2011, 40, 853-859. [CrossRef]

62. Graves, A.R.; Burgess, P.J.; Palma, J.H.N.; Keesman, K.J.; van der Werf, W.; Dupraz, C.; van Keulen, H.; Herzog, F.; Mayus, M. Implementation and calibration of the parameter-sparse Yield-SAFE model to predict production and land equivalent ratio in mixed tree and crop systems under two contrasting production situations in Europe. Ecol. Model. 2010, 221, 1744-1756. [CrossRef] 
63. Balandier, P.; De Montard, F.X.; Curt, T. Root competition for water between trees and grass in a silvopastoral plot of ten-year-old Prunus avium. In Ecological Basis of Agroforestry; CRC Press Taylor \& Francis Group: Boca Raton, FL, USA, 2003; pp. 253-270. ISBN 9781420043365.

64. Cardinael, R.; Chevallier, T.; Cambou, A.; Béral, C.; Barthès, B.G.; Dupraz, C.; Durand, C.; Kouakoua, E.; Chenu, C. Increased soil organic carbon stocks under agroforestry: A survey of six different sites in France. Agric. Ecosyst. Environ. 2017, 236, 243-255. [CrossRef]

65. Stephenson, N.L.; Das, A.J.; Condit, R.; Russo, S.E.; Baker, P.J.; Beckman, N.G.; Coomes, D.A.; Lines, E.R.; Morris, W.K.; Rüger, N.; et al. Rate of tree carbon accumulation increases continuously with tree size. Nature 2014, 507, 90-93. [CrossRef] [PubMed]

66. Cubera, E.; Nunes, J.M.; Madeira, M.; Gazarini, L. Influence of Quercus ilex trees on herbaceous production and nutrient concentrations in southern Portugal. J. Plant Nutr. Soil Sci. 2009, 172, 565-571. [CrossRef]

67. Rivest, D.; Rolo, V.V.; López-Díaz, L.; Moreno, G.; Lopez-Diaz, L.; Moreno, G. Shrub encroachment in Mediterranean silvopastoral systems: Retama sphaerocarpa and Cistus ladanifer induce contrasting effects on pasture and Quercus ilex production. Agric. Ecosyst. Environ. 2011, 141, 447-454. [CrossRef]

68. López-Díaz, M.L.; Rolo, V.; Benítez, R.; Moreno, G. Shrub encroachment of Iberian dehesas: Implications on total forage productivity. Agrofor. Syst. 2015, 89, 587-598. [CrossRef]

69. Palma, J.H.N.; Graves, A.R.; Crous-Duran, J.; Upson, M.; Paulo, J.A.; Oliveira, T.; García de Jalón, S.; Burgess, P.J. Yield-SAFE Model Improvements. Report for Milestone 29 (6.4) of the AGFORWARD Project; FP7 AGFORWARD Project; European Comission: Brussels, Belgium, 2016.

70. Van Keulen, H. Nitrogen Requirements of Rice with Special Reference to Java; Central Research Institute for Agriculture: Bogor, Indonesia, 1977; No. 30; pp. 1-67.

71. Van Keulen, H. Graphical Analysis of Annual Crop Response. Agric. Syst. 1982, 9, 113-126. [CrossRef]

72. Van Keulen, H.; Wolf, J. Crop. Production as Determined by Nutrient Availability. In Modelling of Agricultural Production: Weather, Soils and Crops; Simulation Monographs: Wageningen, The Netherlands, 1986; pp. 153-181.

(C) 2020 by the authors. Licensee MDPI, Basel, Switzerland. This article is an open access article distributed under the terms and conditions of the Creative Commons Attribution (CC BY) license (http://creativecommons.org/licenses/by/4.0/). 